\title{
Effects of Anthropogenic Activities on the Elemental Concentration in Surface Sediment of Oxbows
}

\author{
Zsuzsanna Balogh • Sándor Harangi • \\ János Tamás Kundrát • István Gyulai • \\ Béla Tóthmérész • Edina Simon
}

Received: 24 June 2015 / Accepted: 27 November 2015

(C) Springer International Publishing Switzerland 2015

\begin{abstract}
The Upper Tisza floodplain region provides a mosaic of aquatic habitats including a series of oxbows. Inorganic contaminants can accumulate in the sediment; thus, the sediment is good indicator of the contamination of these oxbows. Our aim was to explore the effects of anthropogenic activities on the concentration of elements and also to study the influence of vegetation types on the element in surface sediment of oxbows. We studied eight oxbows: two of them were protected, four of them were used for fishing and two of them were contaminated with domestic sewage. The following elements were measured with MP-AES in surface sediment: $\mathrm{Al}, \mathrm{Cr}, \mathrm{Cu}, \mathrm{Fe}, \mathrm{Mn}, \mathrm{Pb}$ and $\mathrm{Zn}$. The elemental concentration was compared to the toxicity classes of Environmental Protection Agency (EPA), and the assessment of the level of toxicity was based on this comparison. We found that studied oxbows were different from each other based on the elemental concentrations of sediment using canonical discriminant analysis and analysis of variance. Based on the elemental concentration in surface sediment of oxbows, separation
\end{abstract}

\footnotetext{
Z. Balogh $\cdot$ S. Harangi $\cdot$ J. T. Kundrát $\cdot$ E. Simon $(\bowtie)$

Department of Ecology, University of Debrecen, Debrecen P. O. Box 71, H-4010, Hungary

e-mail: edina.simon@gmail.com

I. Gyulai

Department of Hydrobiology, University of Debrecen, Debrecen P. O. Box 71, H-4010, Hungary

B. Tóthmérész

MTA-DE Biodiversity and Ecosystem Services Research Group, Debrecen P. O. Box 71, H-4010, Hungary
}

was also found among vegetation types. But significant difference was not found in the concentrations of elements based on vegetation types. Our results demonstrated that the anthropogenic activities had remarkable effects on the elemental concentration of surface sediment in oxbows. Our findings suggest that the sediment is useful to assess the effects of anthropogenic activities on elemental concentrations of oxbows.

Keywords Heavy metals · Aquatic vegetation · MPAES · Abiotic indicator

\section{Introduction}

Floodplain ecosystems are one of the most productive ecosystems on the Earth (Tockner and Stanford 2002). Floodplains provide high diversity of aquatic habitats and many vertebrate uses these habitats as nursery, nesting and feeding places (Ward et al. 1999; Robinson et al. 2002; Sandu et al. 2004). The natural habitats are threatened in the floodplains; thus, floodplains have endangered status (Varga et al. 2013). The region of the Upper Tisza (North-Hungary, Central Europe) is rich in oxbows: more than 160 oxbows are along the river Tisza (Pálfai 2001; Lukács et al. 2009). These oxbows were formed by natural cut off meander or by river control. The river control produced drastic changes in the ecosystem which are related to increased anthropogenic activities in the floodplain area (Varga et al. 2013). These anthropogenic activities include changes in traditional land use, farming intensification, 
irrigation and pesticides fertilizers machinery, which played important role in the floodplain area (Varga et al. 2013).

Anthropogenic activities cause higher metal concentrations in aquatic environments (Sarmani et al. 1992; Virkanen 1998). These activities influence sediments through increased load and leads to an increased metal transport to the biosphere (Lindström 2001). Recently, water-influenced natural systems have suffered the most through anthropogenic influences (Varga et al. 2013). The sources of heavy metals are various: natural like weathering of soil and bedrock, and anthropogenic, such as industry and agriculture (Lindström 2001). In 2000, there were two large mining disasters in Romania, which contaminated the whole Tisza river basin by means of the flood of the Tisza River (Szabó et al. 2010). Moreover, there are regular contamination events in the catchment area of Tisza River from the Romanian mining area (Gosztonyi et al. 2011). The suspended particulate material was settled and buried in the sediment so the oxbows are functioning as sediment trap (Papp et al. 2007). The sediment is a good indicator of the contamination of oxbows because many organic and inorganic contaminants, especially heavy metals, can accumulate in the sediment (Bentivegna et al. 2004).

Aquatic macrophytes, both living and dead, are heavy metal accumulators (Keskinkan et al. 2003). Earlier studies reported that aquatic plants were used for the removal of heavy metals from sediments (Wang et al. 1996; Schneider et al. 1999; Keskinkan et al. 2003). Sawidis et al. (1995) concluded that the accumulation from sediment was dependent on the metals properties. Aquatic roots can accumulate heavy metals in higher concentration than leaves, while stem and flowers can accumulate metals in the lowest concentrations (Sawidis et al. 1995). Many studies demonstrated that aquatic flora and particularly the sediments reflect the metal content of their environment and the aquatic macrophytes have effect on the lake's physical and chemical environment (Harding and Whitton 1978; Sawidis et al. 1995; Lukács et al. 2011).

The aim of the paper is to study the effects of anthropogenic activities and vegetation types on elemental concentrations of surface sediment. Our hypothesis was that elemental concentration is higher in the fishing oxbows and sewage-contaminated oxbows than in the protected oxbows. Submerged macrophytes may or may not be rooted to the sediment (Greenway 1993; Thomas et al. 1995) so they can accumulate metals both from the water and from the sediment (Denny 1980; Aulio 1986). Several studies have demonstrated that submerged macrophytes accumulate heavy metals directly from the water (Dunbabin and Bowmer 1992; Cardwell et al. 2002). This explains that the uptake of metals by submerged macrophytes was higher than the uptake by emergent aquatic macrophytes (Dunbabin and Bowmer 1992; Albers and Camardese 1993; Cardwell et al. 2002). The emergent macrophytes' element uptake by roots is the primary source of metal from the sediment (Crowder 1991). The uptake of metals in leaves is lower from the ambient water than in roots (Crowder 1991). Our hypothesis was that lower elemental concentration is found near the submerged and emergent aquatic macrophytes than near the open water surface sediment.

\section{Materials and Methods}

\subsection{Study Area}

The study area is in the Upper Tisza region (NorthEastern Hungary, Central Europe) in the catchment area of the Tisza River. One part of this active floodplain area has conservation priority and another part is a Natura 2000 site within the Hortobágy National Park (Varga et al. 2015). The oxbows were located near the Hungarian-Ukrainian border. The following eight oxbows were studied in the Upper Tisza region: Boroszlókerti-Holt-Tisza, Foltos-kerti-Holt-Tisza, Gyürei-HoltTisza, Vargaszegi-Holt-Tisza, Lónyai-morotva, Tuzséri-Holt-Tisza, Szabolcsi-Holt-Tisza and Tímári Morotva-tó. The Boroszló-kerti- and Foltos-kerti-HoltTisza are under Hortobágy National Park's authority so these oxbows are protected, while the water of Gyürei-, Vargaszegi-Holt-Tisza, Tuzséri Holt-Tisza and Szabolcsi-Holt-Tisza oxbows are under different anglers association's authority. Therefore, the monitoring of these oxbows is important from human point of view because heavy metals can getting into the food chain and accumulate in the living beings (Gosztonyi et al. 2011). Water of other two oxbows (Lónyai-morotva and Tímári Morotva-tó) were contaminated with domestic sewage. These oxbows are under self-govering's authority so this oxbow is negligent and presumably it is contaminated with domestic sewage (Table 1).

Oxbows were located in the floodplain area; thus, they are connected to the Tisza River during floodplain 
Table 1 Characteristics of the studied oxbows

\begin{tabular}{llcc}
\hline Name of the oxbow & Utilization & GPS coordinates & $\begin{array}{c}\text { Depth of the oxbows } \\
(\mathrm{cm}, \mathrm{mean} \pm \mathrm{SD})\end{array}$ \\
\hline Boroszló-kerti-Holt-Tisza & Protected oxbow & $48^{\circ} 05^{\prime} 10^{\prime \prime} \mathrm{N}, 22^{\circ} 24^{\prime} 41^{\prime \prime} \mathrm{E}$ & $191 \pm 113$ \\
Foltos-kerti-Holt-Tisza & Protected oxbow & $48^{\circ} 06^{\prime} 01^{\prime \prime} \mathrm{N}, 22^{\circ} 23^{\prime} 02^{\prime \prime} \mathrm{E}$ & $119 \pm 73$ \\
Gyürei-Holt-Tisza & Fishing oxbow & $48^{\circ} 11^{\prime} 03^{\prime \prime} \mathrm{N}, 22^{\circ} 15^{\prime} 58^{\prime \prime} \mathrm{E}$ & $197 \pm 257$ \\
Vargaszegi-Holt-Tisza & Fishing oxbow & $48^{\circ} 06^{\prime} 15^{\prime \prime} \mathrm{N}, 22^{\circ} 33^{\prime} 57^{\prime \prime} \mathrm{E}$ & $131 \pm 111$ \\
Tuzséri-Holt-Tisza & Fishing oxbow & $48^{\circ} 19^{\prime} 24^{\prime \prime} \mathrm{N}, 22^{\circ} 05^{\prime} 58^{\prime \prime} \mathrm{E}$ & $103 \pm 54$ \\
Szabolcsi-Holt-Tisza & Fishing oxbow & $48^{\circ} 10^{\prime} 20^{\prime \prime} \mathrm{N}, 21^{\circ} 30^{\prime} 18^{\prime \prime} \mathrm{E}$ & $57 \pm 36$ \\
Tímári Morotva-tó & Sewage-contaminated oxbow & $48^{\circ} 08^{\prime} 36^{\prime \prime} \mathrm{N}, 21^{\circ} 27^{\prime} 03^{\prime \prime} \mathrm{E}$ & $129 \pm 62$ \\
Lónyai morotva & Sewage-contaminated oxbow & $48^{\circ} 18^{\prime} 48^{\prime \prime} \mathrm{N}, 22^{\circ} 15^{\prime} 46^{\prime \prime} \mathrm{E}$ & $159 \pm 57$ \\
\hline
\end{tabular}

events. The oxbows average depth varies between 1 and $2 \mathrm{~m}$, except the Szabolcsi-Holt-Tisza which was very shallow. During our research, 62 sediment samples were collected from the eight oxbows. Surface sediment samples $(0-2 \mathrm{~cm})$ were taken from 7 locations from Tímári Morotva-tó, Tuzséri-, Szabolcsi-, Vargaszegi-, Gyüreiand Foltos-kerti-Holt-Tisza; 9 locations from Lónyaimorotva and 11 locations from Boroszló-kerti-HoltTisza. The aquatic vegetation of the oxbows was extremely diverse. The sediment sampling points were determined by the vegetation types. We identified there were three vegetation types to study the effect of vegetation types on the elemental concentration in the studied oxbows sediment. The first vegetation type was floating leaves aquatic plants; the following species were frequent: Trapa natans, Nymphaea alba, Nuphar lutea, Polygonum amphibium. The second vegetation type was submerged aquatic plants where Myriophillum verticillatum, Potamogeton lucens, Ceratophyllum demersum and Utricularia vulgaris species were typical. The third vegetation type was emergent aquatic plants which were characterized with the Phragmites australis, Typha angustifolia and Typha latifolia. The control was the open water without vegetation.

\subsection{Sample Collection and Preparation}

The surface sediment samples were collected with a core sampling in June and July 2013. Plexiglas (46 mm ID) gravity corer was used to take the surface samples. The surface sediment samples were stored at $4{ }^{\circ} \mathrm{C}$ until sample preparation to protect them against microbial saprophytic activity. The top $2 \mathrm{~cm}$ thick wet surface sediment samples were air-dry during 1 week. Then samples were homogenised with agate mortar. From air dried sediment $0.2 \mathrm{~g}$ samples were measured on an analytical balance (Analytical Balance Sartorius 1702004) and samples dried (WTB Binder ED 53) at $105^{\circ} \mathrm{C}$ for $4 \mathrm{~h}$.

\subsection{Elemental Analysis}

For elemental analysis, $0.2 \mathrm{~g}$ of sediment samples was digested in glass beakers with $5 \mathrm{ml} 65 \%(\mathrm{~m} / \mathrm{m})$ nitric acid at $80{ }^{\circ} \mathrm{C}$ in three replicates. After $1 \mathrm{ml}$ of $30 \%$ $(\mathrm{m} / \mathrm{m})$ hydrogen peroxide and $5 \mathrm{ml}$ of double deionized water were added to the samples, they were dried again. The digested samples were diluted to $10 \mathrm{ml}$ using $1 \%$ $(\mathrm{m} / \mathrm{m})$ nitric acid and ultrasonic mixer. The elemental concentrations were measured with Microwave PlasmaAtomic Emission Spectrometer (MP-AES) (Agilent MP-AES 4100). The following elements were determined: $\mathrm{Al}, \mathrm{Cr}, \mathrm{Cu}, \mathrm{Fe}, \mathrm{Mn}, \mathrm{Pb}$ and $\mathrm{Zn}$. Certified reference material BCR 700 was included in each batch of samples during the measurement. The analytical error was less than $\pm 10 \%$ of the certified values for the metals.

\subsection{Determination of Organic Matter Content}

After drying, three repeated samples $(0.2 \mathrm{~g})$ were cremated at $550{ }^{\circ} \mathrm{C}$ for $4 \mathrm{~h}$ in a muffle furnace (Nabertherm L5/C6, Germany). To determine the organic matter content of surface sediment, the loss on ignition method was used. The loss on ignition was calculated with the following equation: LOI550=100 (DW105-DW550)/ WS, where LOI550 was the percentage of loss on ignition at $550{ }^{\circ} \mathrm{C}, \mathrm{DW} 105$ was the dry weight of samples at $550{ }^{\circ} \mathrm{C}$ and DW550 was the weight of the sample at $550{ }^{\circ} \mathrm{C}$ (Bengtsson and Enell 1986; Heiri et al. 2001). 


\subsection{Statistical Analysis}

SPSS/PC + and Canoco packages were used during the calculations. The elemental concentrations of sediment in the oxbows and vegetation types were analysed by canonical discriminant analysis (CDA). Homogeneity of variance was tested by Levene test. The normal distribution was tested with a Shapiro-Wilk test. The differences among oxbows and vegetation types on elemental concentrations and organic matter contents of surface sediment were tested by two-way ANOVA. The factors were the oxbows and the vegetation types. In the case of significant differences, Tukey's Multiple Comparison test was used. The correlation between organic matter content and elemental concentrations was studied with Pearson Rank correlation.

\section{Results}

\subsection{Effects of Anthropogenic Activities} on the Elemental Concentrations in Surface Sediment

Table 2 contains the elemental concentrations of surface sediments. The concentrations of elements in the surface sediment of the oxbows were evaluated by CDA. The total variance of the first two axes was $100 \%$. The first axis's variance distribution was $87.4 \%$, while the second axis's variance distribution was $12.6 \%$. The elemental concentrations of surface sediment were separated from each other, but there was overlap between the fishing oxbows and the sewage-contaminated oxbows (Fig. 1). Significant positive correlation were found between the first

Table 2 Trace element concentration of sediment (mean \pm SD) according to use of water

\begin{tabular}{lccl}
\hline Elements & $\begin{array}{l}\text { Protected } \\
\text { oxbows }\end{array}$ & $\begin{array}{l}\text { Fishing } \\
\text { oxbows }\end{array}$ & $\begin{array}{l}\text { Sewage-contaminated } \\
\text { oxbows }\end{array}$ \\
\hline $\mathrm{Al}, \mathrm{g} / \mathrm{kg}$ & $278 \pm 22 \mathrm{a}$ & $263 \pm 62 \mathrm{a}$ & $262 \pm 42 \mathrm{a}$ \\
$\mathrm{Cr}, \mathrm{mg} / \mathrm{kg}$ & $77 \pm 4.6 \mathrm{ab}$ & $67 \pm 17 \mathrm{ac}$ & $71 \pm 14 \mathrm{bc}$ \\
$\mathrm{Cu}, \mathrm{mg} / \mathrm{kg}$ & $67 \pm 12 \mathrm{ab}$ & $55 \pm 14 \mathrm{ac}$ & $58 \pm 15 \mathrm{bc}$ \\
$\mathrm{Fe}, \mathrm{g} / \mathrm{kg}$ & $720 \pm 75 \mathrm{ab}$ & $589 \pm 136 \mathrm{ac}$ & $664 \pm 180 \mathrm{bc}$ \\
$\mathrm{Mn}, \mathrm{g} / \mathrm{kg}$ & $21 \pm 6.2 \mathrm{ab}$ & $12 \pm 5.1 \mathrm{ab}$ & $21 \pm 17 \mathrm{bd}$ \\
$\mathrm{Pb}, \mathrm{mg} / \mathrm{kg}$ & $78 \pm 19 \mathrm{ac}$ & $87 \pm 23 \mathrm{ac}$ & $89 \pm 25 \mathrm{ac}$ \\
$\mathrm{Zn}, \mathrm{mg} / \mathrm{kg}$ & $157 \pm 22 \mathrm{bd}$ & $211 \pm 85 \mathrm{bc}$ & $216 \pm 60 \mathrm{bc}$
\end{tabular}

Different letters indicate significant differences $(p>0.05)$ discriminant function and the concentration of aluminium $(r=0.12)$, chromium $(r=0.28)$ and copper $(r=0.31)$. Significant negative correlation was found between the first discriminant function and the concentration of zinc $(r=-0.31)$. Significant positive correlation were found between the second discriminant function and the concentration of manganese $(r=0.69)$, iron $(r=0.35)$ and lead $(r=0.16)$.

Using variance analysis (ANOVA), the concentration of chromium $(F=3.536 ; p=0.035)$, copper $(F=4.17 ; p=$ $0.020)$, zinc $(F=4.6 ; p=0.014)$, manganese $(F=3.75$; $p=0.002)$ and iron $(F=5.31 ; p=0.008)$ differed significantly between the oxbows. The chromium and the copper concentration were the highest in the protected oxbows and significant differences were not found between protected oxbows and fishing oxbows. Significant differences were found between protected oxbows and sewage-contaminated oxbows. The manganese concentration was similar in protected oxbows and sewage-contaminated oxbows, and significant differences were not found between protected oxbows and fishing oxbows. Zinc concentration was the highest in the protected oxbows, and significant differences were found between protected oxbows and fishing oxbows and sewage-contaminated oxbows. The Fe concentration was the highest in the protected oxbows and significant differences were not found between protected oxbows and fishing oxbows, but significant differences were found between protected oxbows and sewagecontaminated oxbows (Table 2).

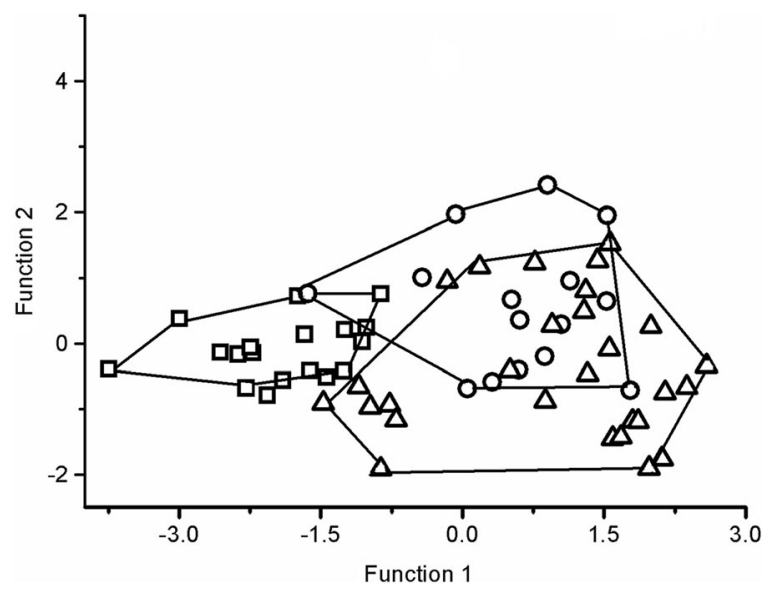

Fig. 1 Canonical discriminant analysis of the oxbows based on the elemental concentrations in surface sediment $(\mathrm{mg} / \mathrm{kg})$. Notations: square-protected oxbows, circle-fishing oxbows, triangle - sewage-contaminated oxbows 
3.2 Elemental Concentrations in Surface Sediment Based on Vegetation Types

The total variances of the first two axes were $90.3 \%$ using canonical discriminant analysis. The variance of the first axis was $65.8 \%$, while the variance of the second axis was $24.5 \%$. The elemental concentration of the sediment of oxbows was not separated from each other based on aquatic vegetation types (Fig. 2). Significant positive correlation was found between the second discriminant function and the concentration of aluminium $(r=0.737)$, iron $(r=0.90)$, chromium $(r=$ $0.8)$, manganese $(r=0.82)$, copper $(r=0.66)$ and lead $(r=0.44)$. Significant negative correlation was found between the third discriminant function and the concentration of zinc $(r=-0.41)$. The effect of the first discriminant function was not significant.

Significant difference was found in the concentrations of iron $(F=3.69 ; p=0.018)$ among aquatic vegetation types. In the case of iron concentration, significant differences were found between open water sampling sites and emergent aquatic vegetation types and open water sampling sites and floating leaves plants sampling sites (Table 3).

\section{Discussion}

The aim of this paper was to explore the differences between protected, fishing and sewage-contaminated

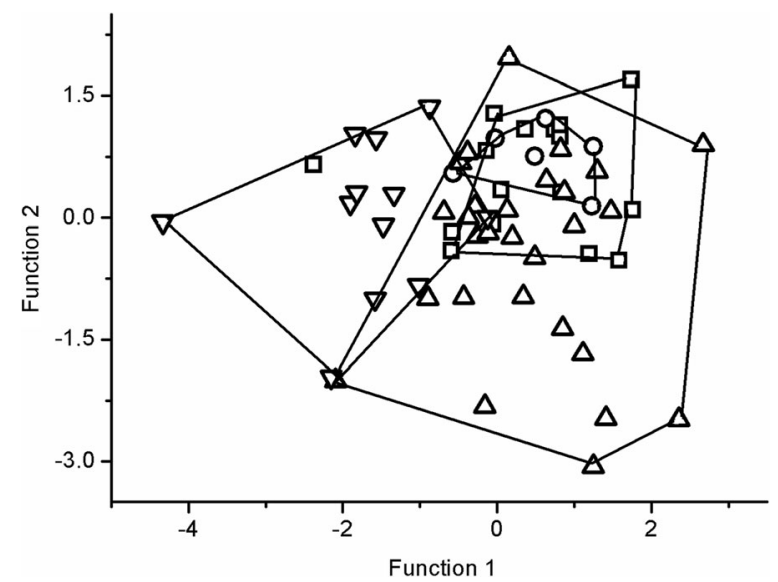

Fig. 2 Canonical discriminant analysis of floating leaves, submerged, emergent vegetation types and open water based on the elemental concentrations of surface sediment $(\mathrm{mg} / \mathrm{kg})$. Notations: square - floating leaves, circle — submerged, triangle — emergent aquatic plants, inverted triangle - open water oxbows in the elemental concentrations of surface sediment, and to study the correlation between elemental concentrations of surface sediments and aquatic vegetation types in oxbows of the Upper Tisza region. Our results demonstrated that there are differences among the elemental concentrations of surface sediment of oxbows based on anthropogenic activities. But, our results did not show correlation between elemental concentrations of surface sediments and the aquatic vegetation types, except in the case of iron.

The elemental concentrations of surface sediments were compared to the Environmental Protection Agency values (Baudo and Muntau 1990). Our results showed that all studied oxbows were heavily contaminated for $\mathrm{Cu}, \mathrm{Mn}$ and $\mathrm{Fe}$ (Table 2). The protected oxbows were heavily contaminated for $\mathrm{Cr}$ and the fishing oxbows and sewage-contaminated oxbows were moderately polluted for Cr. Fishing oxbows and sewage-contaminated oxbows were heavily contaminated for $\mathrm{Zn}$ and protected oxbows were moderately polluted for $\mathrm{Zn}$.

In Hungary the mean geochemical concentration in the upper level $(0-10 \mathrm{~cm})$ of floodplain sediments is $25 \mathrm{mg} \mathrm{kg}^{-1}$ for $\mathrm{Cr}, 25 \mathrm{mg} \mathrm{kg}^{-1}$ for $\mathrm{Cu}, 21 \mathrm{mg} \mathrm{kg}^{-1}$ for $\mathrm{Pb}, 95 \mathrm{mg} \mathrm{kg}^{-1}$ for $\mathrm{Zn}, 25,000 \mathrm{mg} \mathrm{kg}^{-1}$ for $\mathrm{Al}_{2} \mathrm{O}_{3}$, $35,000 \mathrm{mg} \mathrm{kg}^{-1}$ for $\mathrm{Fe}_{2} \mathrm{O}_{3}$ and $1000 \mathrm{mg} \mathrm{kg}^{-1}$ for $\mathrm{MnO}$ (Ódor et al. 1997). Based on this report, all of studied elements exceed the geochemical concentration. The high $\mathrm{Mn}$ and $\mathrm{Fe}$ concentration in all oxbows originate from the geochemical background of Upper Tisza region. Heavy metals adsorption plays a significant role of organic matter, iron and manganese oxides (Jain and Ram 1997). The particle size of the sediments is in inverse ratio to the manganese and iron adsorption in

Table 3 Trace element concentration of sediment (mean \pm SD) based on vegetation of oxbows

\begin{tabular}{lcccc}
\hline Elements & $\begin{array}{l}\text { Floating } \\
\text { leaves }\end{array}$ & Submerged & Emergent & Open water \\
\hline $\mathrm{Al}, \mathrm{g} / \mathrm{kg}$ & $263 \pm 36 \mathrm{a}$ & $264 \pm 16 \mathrm{a}$ & $257 \pm 59 \mathrm{a}$ & $298 \pm 341 \mathrm{a}$ \\
$\mathrm{Cr}, \mathrm{mg} / \mathrm{kg}$ & $74 \pm 8.3 \mathrm{a}$ & $77 \pm 3.5 \mathrm{a}$ & $66 \pm 17 \mathrm{a}$ & $76 \pm 9.1 \mathrm{a}$ \\
$\mathrm{Cu}, \mathrm{mg} / \mathrm{kg}$ & $61 \pm 16 \mathrm{a}$ & $62 \pm 8.7 \mathrm{a}$ & $56 \pm 16 \mathrm{a}$ & $63 \pm 8.4 \mathrm{a}$ \\
$\mathrm{Fe}, \mathrm{g} / \mathrm{kg}$ & $615 \pm 107 \mathrm{a}$ & $645 \pm 79 \mathrm{ac}$ & $616 \pm 160 \mathrm{a}$ & $762 \pm 127 \mathrm{bc}$ \\
$\mathrm{Mn}, \mathrm{g} / \mathrm{kg}$ & $14 \pm 4.5 \mathrm{a}$ & $19 \pm 8.9 \mathrm{a}$ & $17 \pm 14 \mathrm{a}$ & $20 \pm 6.6 \mathrm{a}$ \\
$\mathrm{Pb}, \mathrm{mg} / \mathrm{kg}$ & $89 \pm 12 \mathrm{a}$ & $96 \pm 29 \mathrm{a}$ & $80 \pm 28 \mathrm{a}$ & $83 \pm 15 \mathrm{a}$ \\
$\mathrm{Zn}, \mathrm{mg} / \mathrm{kg}$ & $194 \pm 60 \mathrm{a}$ & $175 \pm 25 \mathrm{a}$ & $191 \pm 70 \mathrm{a}$ & $224 \pm 92 \mathrm{a}$ \\
\hline
\end{tabular}

Different letters indicate significant differences $(p>0.05)$ 
the various fractions (Jain and Ram 1997). Therefore, there is a link between high concentration of iron, manganese and oxbows fine-grained clayey silt sediments (Papp et al. 2007).

Compared to our results with earlier studies about elemental concentration in different river surface sediment, our study indicated the moderate level of pollution in the Upper Tisza region. Bird et al. (2003) studied two rivers surface sediment in Romania which was Lapus River and Somes River. The concentration value of $\mathrm{Cu}$ (Lapus River, $240 \mathrm{mg} \mathrm{kg}^{-1}$; Somes River, $220 \mathrm{mg} \mathrm{kg}^{-1}$ ), $\mathrm{Pb}$ (Lapus River, $200 \mathrm{mg} \mathrm{kg}^{-1}$; Somes River, $97 \mathrm{mg} \mathrm{kg}^{-1}$ ) and $\mathrm{Zn}$ (Lapus River, $770 \mathrm{mg} \mathrm{kg}{ }^{-1}$; Somes River, $1200 \mathrm{mg} \mathrm{kg}^{-1}$ ) was higher in the surface sediment than our findings (Bird et al. 2003). Vystavna et al. (2012) studied the metal concentration in the sediment of Udy River and Lopan River in Ukraine. They found lower $\mathrm{Cu}$ (Udy River, $33 \pm 39 \mathrm{mg} \mathrm{kg}^{-1}$; Lopan River, $42 \pm 32 \mathrm{mg} \mathrm{kg}^{-1}$ ), $\mathrm{Pb}$ (Udy River, $15 \pm$ $7 \mathrm{mg} \mathrm{kg}^{-1}$; Lopan River, $30 \pm 17 \mathrm{mg} \mathrm{kg}^{-1}$ ) and $\mathrm{Zn}$ (Udy River, $59 \pm 35 \mathrm{mg} \mathrm{kg}^{-1}$; Lopan River, $111 \pm$ $95 \mathrm{mg} \mathrm{kg}^{-1}$ ) concentration in sediment than in the Upper Tisza region. Hiller et al. (2010) studied two water reservoirs sediment in Slovakia. In the case of $\mathrm{Cu}$ (Ruzin, $382 \pm 191 \mathrm{mg} \mathrm{kg}^{-1}$; Velke Kozmalovce, $78 \pm$ $22 \mathrm{mg} \mathrm{kg}^{-1}$ ) and $\mathrm{Zn}$ (Ruzin, $517 \pm 209 \mathrm{mg} \mathrm{kg}^{-1}$; Velke Kozmalovce, $469 \pm 69 \mathrm{mg} \mathrm{kg}^{-1}$ ) higher concentration was found than in our case. The $\mathrm{Pb}$ concentration in Ruzin surface sediment was similar to our findings $(79 \pm$ $22 \mathrm{mg} \mathrm{kg}^{-1}$ ), and in the case of Velke Kozmalovce, the $\mathrm{Pb}$ concentration was lower $66 \pm 8 \mathrm{mg} \mathrm{kg}^{-1}$ compared to our results.

The metal accumulation is known to vary significantly between aquatic macrophytes species (Albers and Camardese 1993; Cardwell et al. 2002). Some studies demonstrated that aquatic macrophytes as emergent plants are an integral part of all wetland functions (Dunbabin and Bowmer 1992). Our results showed that there were no significant differences between aquatic vegetation types in the elemental concentration of sediment. Submerged aquatic macrophytes mostly can uptake higher quantity of metals than emergent aquatic macrophytes (Albers and Camardese 1993; Cardwell et al. 2002). Earlier studies demonstrated metal uptake correlation between aquatic macrophytes and sediment concentrations. These studies found poor correlation between aquatic macrophytes and sediment concentrations (Jackson and Kalff 1993; Cardwell et al. 2002). Mishra et al. (2008) concluded that significant correlation was not found between metal concentrations of sediment and metal concentrations of aquatic macrophytes root.

\section{Conclusions}

In this study, the effects of anthropogenic activities and vegetation types were analysed to the elemental concentration of the sediment of oxbows. Earlier studies demonstrated that the agricultural runoff (zinc phosphate chemical fertilizer), domestic wastes (Sawidis et al. 1995). particle size (Jain and Ram 1997) and vegetation structure (Szabó et al. 2009; Szalai 1998) have effect on the elemental concentrations of oxbows. Therefore, the anthropogenic activities and vegetation have remarkable effect on the elemental concentration of sediment. Our results demonstrated that the protected and fishing oxbows were heavily contaminated with $\mathrm{Cr}$. For $\mathrm{Zn}$, our results demonstrated that the fishing oxbows and sewage-contaminated oxbows were heavily contaminated. In the case of $\mathrm{Cu}, \mathrm{Mn}$ and $\mathrm{Fe}$, all oxbows were contaminated heavily. In the case of sewagecontaminated oxbows, our results indicated that remarkable differences were not found similar to the fishing oxbows. In Hungary, especially the industrial wastewater contains heavy metals in high concentration (Gulyás et al. 2015). At the same time, the ammonium, phosphorus and organic material contents of commercial wastewater are high (Kalló 1995; Domokos et al. 2005; Szabó et al. 2008). In summary, our results show that the anthropogenic activities and geochemical background were the main factors which play important role in the contaminant level of the oxbows. However, the sediment is useful to assess differences between fishing, sewage-contaminated-, and protected oxbows on elemental concentrations of surface sediment.

Acknowledgments The research was partially supported by the Internal Research Project of the University of Debrecen (E. Simon), by the TÁMOP 4.2.1./B-09/1/KONV-2010-0024 project and by the SROP-4.2.2.B-15/1/KONV20150001 project.

\section{References}

Albers, P. H., \& Camardese, M. B. (1993). Effects of acidification on metal accumulation by aquatic plants and invertebrates 1 . 
Constructed wetlands. Environmental Toxicology and Chemistry, 12, 959-967.

Aulio, K. (1986). Aquatic macrophytes as indicators of heavy metal pollution. Publications of the Water Research Institute, 68, 171-174.

Baudo, R., \& Muntau, H. (1990). Lesser known in-place pollutants and diffuse source problems. In R. Baudo, J. Giesy, \& H. Muntau (Eds.), Sediments: chemistry and toxicity of in-place pollutants (pp. 1-15). Florida: Lewis Publisher.

Bengtsson, L., \& Enell, M. (1986). Chemical analysis. In B. E. Berglund (Ed.), Handbook of holocene palaeoecology and palaeohydrology (pp. 423-445). Chichester: Wiley.

Bentivegna, C. S., Alfano, J. E., Bugel, S. M., \& Czechowicz, K. (2004). Influence of sediment characteristics on heavy metal toxicity in an urban marsh. Urban Habitats, 2, 91-111.

Bird, G., Brewer, P. A., Macklin, M. G., Balteanu, D., Driga, B., Serban, M., \& Zaharia, S. (2003). The solid-state partitioning of contaminant metals and As in river channel sediments of the mining affected Tisa drainage basin, northwestern Romania and eastern Hungary. Applied Geochemistry, 18, 1583-1595.

Cardwell, A. J., Hawker, D. W., \& Greenway, M. (2002). Metal accumulation in aquatic macrophytes from south east Queensland, Australia. Chemosphere, 48, 653-663.

Crowder, A. (1991). Acidification, metals and macrophytes. Environmental Pollution, 71, 171-203.

Denny, P. (1980). Solute movement in submerged angiosperms. Biological Reviews, 55, 65-92.

Domokos, E., Holenda, B., Utasi, A., Rédey, Á., \& Fazakas, J. (2005). Effect of long retention time in the settler on phosphorus removal from communal wastewater. Environmental Science and Pollution Research, 12, 306-309.

Dunbabin, J. S., \& Bowmer, K. H. (1992). Potential use of constructed wetlands for treatment of industrial wastewaters containing metals. Science of the Total Environment, 111, 151-168.

Gosztonyi, G., Braun, M., Prokisch, J., \& Szabó, S. (2011). Examination of zinc and iron mobilization with acid treatments and the metal content of maize and stinging nettle in the active floodplain of the River Tisza. Carpathian Journal of Earth and Environmental Sciences, 6, 25-33.

Greenway, M. (1993). Wetlands for waste water and wildlife - an ecologist's perspective. Water conservation and reuse grey issues, clear solutions. Australian Water and Wastewater Association.

Gulyás, G., Pistás, V., Fazekas, B., \& Kárpáti, Á. (2015). Heavy metal balance in a communal wastewater treatment plant. Hungarian Journal of Industry and Chemistry, 43, 1-5.

Harding, J. P. C., \& Whitton, B. A. (1978). Zinc, cadmium and lead in water, sediments and submerged plants of the Derwent Reservoir, Northern England. Water Research, 12, 307-316.

Heiri, O., Lotter, A. F., \& Lemcke, G. (2001). Loss on ignition as a method for estimating organic and carbonate content in sediments: reproducibility and comparability of results. Journal of Paleolimnology, 25, 101-110.

Hiller, E., Jurkovic, L., \& Sutriepka, M. (2010). Metals in the surface sediments of selected water reservoirs, Slovakia. Bulletin of Environmental Contamination and Toxicology, 84, 635-640.
Jackson, L. J., \& Kalff, J. (1993). Patterns in metal content of submerged aquatic macrophytes: the role of plant growth form. Freshwater Biology, 29, 351-359.

Jain, C. K., \& Ram, D. (1997). Adsorption of lead and zinc on bed sediments of the River Kali. Water Research, 31, 154-162.

Kalló, D. (1995). Wastewater purification in Hungary. In D. W. Miog \& F. A. Mumpton (Eds.), Natural zeolites (pp. 341350). Brockport, New York: International community of natural zeolites.

Keskinkan, O., Goksu, M. Z. L., Yuceer, A., Basibuyuk, M., \& Forster, C. F. (2003). Heavy metal adsorption characteristics of a submerged aquatic plant (Myriophyllum spicatum). Process Biochemistry, 39, 179-183.

Lindström, M. (2001). Urban land use influences on heavy metal fluxes and surface sediment concentrations of small oxbows. Water, Air, and Soil Pollution, 126, 363-383.

Lukács, B. A., Dévai, G., \& Tóthmérész, B. (2009). Aquatic macrophytes as bioindicators of water chemistry in nutrient rich backwaters along the Upper-Tisza river (in Hungary). Phytocoenologia, 39, 287-293.

Lukács, B. A., Dévai, G., \& Tóthmérész, B. (2011). Small scale macrophyte-environment relationship in an oxbow-lake of the Upper-Tisza valley (Hungary). Community Ecology, 12, 259-263.

Mishra, V. K., Upadhyay, A. R., Pandey, S. K., \& Tripathi, B. D. (2008). Concentrations of heavy metals and aquatic macrophytes of Govind Ballabh Pant Sagar an anthropogenic lake affected by coal mining effluent. Environmental Monitoring and Assessment, 141, 49-58.

Ódor, L., Horváth, I., \& Fügedi, U. (1997). Low-density geochemical mapping in Hungary. Journal of Geochemical Exploration, 60, 55-66.

Papp, I., Braun, M., Szalóki, I., \& Leermakers, M. (2007). Investigation of the effects of the Baia Borsa pollution event in the sediment of the Boroszlókert Oxbow Lake of the Tisza. Acta Geographica ac Geologica et Meteorologica Debrecina, 2, 181-186.

Robinson, C. T., Tockner, K., \& Ward, J. V. (2002). The fauna of dynamic riverine landscapes. Freshwater Biology, 47, 661677.

Sandu, C., Puky, M., \& Gorogh, Z. (2004). Water chemical characterization of upper Tisza oxbow lakes after a long floodfree period. Proceedings of the Institute of Biology, 6, 133148.

Sarmani, S., Abdullah, M. P., Baba, I., \& Majid, A. A. (1992). Inventory of heavy metals and organic micropollutants in an urban water catchment drainage basin. Developments in Hydrobiology, 75, 669-674.

Sawidis, T., Chettri, M. K., Zachariadis, G. A., \& Siratis, J. A. (1995). Heavy metals in aquatic plants and sediments from water systems in Macedonia, Greece. Ecotoxicology and Environmental Safety, 32, 73-80.

Schneider, I. A. H., Rubio, J., \& Smith, R. W. (1999). Effect of some mining chemicals on biosorption of $\mathrm{Cu}$ (II) by the nonliving biomass of the freshwater macrophyte Potamogeton lucens. Minerals Engineering, 12, 255-260.

Szabó, S., Szabó, G., Fodor, C., \& Papp, L. (2008). Investigation of two sewage disposal sites from the aspect of environmental impacts on soil and groundwater in the County of HajdúBihar (Hungary). Moravian Geographical Reports, 16, 3745. 
Szabó, S., Gosztonyi, G., \& Juhos, K. (2009). Az üledék nehézfémtartalmának statisztikai elemzése a Felső-Tisza hullámterén (In Hungarian). Statistical analysis of heavy metal content of sediment samples from the floodland of Tisza River. Hidrológiai Közlöny, 89, 50-54.

Szabó, S., Gyosztonyi, G., Babka, B., Dócsi, N., Braun, M., Csorbai, P., Türk, G., Molnár, L. S., Bakosi, B., Szabó, G., Futó, I., Gönczy, S., Ágoston, C., Szabó, M., Szabó, G., \& Prokisch, J. (2010). GIS database of the heavy metals in the floodplain of the Tisza. Studia Universitatis Vasile Goldis Seria Stiintele Vietii, 20, 97-104.

Szalai, Z. (1998). Trace metal pollution and microtopography in a floodplain. Geografia Fisica e Dinamica Quaternaria, 21, $75-78$.

Thomas, P. R., Glover, P., \& Kalaroopan, T. (1995). An evaluation of pollutant removal from secondary treated sewage effluent using a constructed wetland system. Water Science and Technology, 32, 87-93.

Tockner, K., \& Stanford, J. A. (2002). Riverine floodplains: present state and future trends. Environmental Conservation, 29, 308-330.

Varga, K., Dévai, G., \& Tóthmérész, B. (2013). Land use history of a floodplain area during the last 200 years in the Upper-
Tisza Region (Hungary). Regional Environmental Change, 13, 1109-1118.

Varga, K., Szabó, S., Szabó, G., Dévai, G., \& Tóthmérész, B. (2015). Improved land cover mapping using aerial photographs and satellite images. Open Geosciences, 7, 15-26.

Virkanen, J. (1998). Effect of urbanization on metal deposition in the Bay of Töölönlahti, Southern Finland. Marine Pollution Bulletin, 36, 729-738.

Vystavna, Y., Huneau, F., Schäfer, J., Motelica-Heino, M., Blanc, G., Larrose, A., Vergeles, Y., Diadin, D., \& Le Coustumer, P. (2012). Distribution of trace elements in waters and sediments of the Seversky Donets transboundary watershed (Kharkiv region, Eastern Ukraine). Applied Geochemistry, 27, 2077-2087.

Wang, T. C., Weissman, J. C., Ramesh, G., Varadarajan, R., \& Benemann, J. R. (1996). Parameters for removal of toxic heavy metals by water milfoil (Myriophyllum spicatum). Bulletin of Environmental Contamination and Toxicology, 57, 779-786.

Ward, J. V., Tockner, K., \& Schiemer, F. (1999). Biodiversity of floodplain river ecosystems: ecotones and connectivity. Regulated Rivers: Research \& Management, 15, 125-139. 